\title{
Correction to: Mechanisms mediating the relation between reading self-concept and reading comprehension
}

Franziska Maria Locher ${ }^{1} \cdot$ Sarah Becker ${ }^{2} \cdot$ Irene Schiefer $^{2} \cdot{\text { Maximilian } \text { Pfost }^{2}}^{2}$

Published online: 3 June 2020

(C) The Author(s) 2020

\section{Correction to: Eur J Psychol Educ \\ https://doi.org/10.1007/s10212-020-00463-8}

The article Mechanisms mediating the relation between reading self-concept and reading comprehension, written by Franziska Maria Locher, Sarah Becker, Irene Schiefer, and Maximilian Pfost, was originally published electronically on the publisher's internet portal on 23 January 2020 without open access. With the author(s)' decision to opt for Open Choice, the copyright of the article changed on April 2020 to (C) The Author(s) 2020, and the article is forthwith distributed under a Creative Commons Attribution 4.0 International License (https://creativecommons.org/licenses/by/4.0/), which permits use, sharing, adaptation, distribution, and reproduction in any medium or format, as long as you give appropriate credit to the original author(s) and the source, provide a link to the Creative Commons license, and indicate if changes were made.

The original article has been corrected.

Open Access This article is licensed under a Creative Commons Attribution 4.0 International License, which permits use, sharing, adaptation, distribution and reproduction in any medium or format, as long as you give appropriate credit to the original author(s) and the source, provide a link to the Creative Commons licence, and indicate if changes were made. The images or other third party material in this article are included in the article's Creative Commons licence, unless indicated otherwise in a credit line to the material. If material is not included in the article's Creative Commons licence and your intended use is not permitted by statutory regulation or exceeds the permitted use, you will need to obtain permission directly from the copyright holder. To view a copy of this licence, visit http://creativecommons.org/licenses/by/4.0/.

The online version of the original article can be found at https://doi.org/10.1007/s10212-020-00463-8

Franziska Maria Locher franziska.locher@phsg.ch

1 Department of Research on Teaching Profession and Competence Development, St. Gallen University of Teacher Education, 9000 St. Gallen, Switzerland

2 Department of Educational Research, University of Bamberg, Bamberg, Germany 